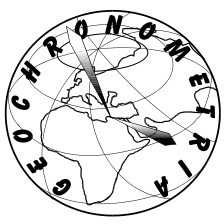

\title{
DENDROCLIMATOLOGICAL ANALYSIS OF WILD PEAR PYRUS PYRASTER (L.) BURGSD. FROM BIEDRUSKO MILITARY AREA (WEST POLAND) - PRELIMINARY STUDY
}

\author{
ANNA CEDRO ${ }^{1}$ and WOJCIECH ANTKOWIAK ${ }^{2}$ \\ ${ }^{1}$ University of Szczecin, Faculty of Geosciences, Laboratory of Climatology and Marine Meteorology, \\ Mickiewicza 16, 70-383 Szczecin, Poland \\ ${ }^{2}$ University of Life Sciences in Poznań, Department of Botany, Wojska Polskiego 71c, 60-625 Poznań, Poland
}

Received 9 October 2014

Accepted 11 January 2016

\begin{abstract}
European wild pear (Pyrus pyraster, syn. Pyrus communis subsp. pyraster L.) is widely distributed in Europe, but rarely studied by dendrochronologists. This preliminary study was aimed to assess the age and effect of climate on tree-ring width in the largest Polish population of P. pyraster, in Biedrusko military area (western Poland). On the basis of samples from 21 trees, a chronology (BIE) was constructed, covering 45 years (1963-2007). Mean tree-ring width in the studied trees is $1.92 \mathrm{~mm}$. The performed analyses (pointer years, correlations, and response function) indicate that tree-ring width is strongly dependent on weather conditions in the year preceding formation of the tree-ring. Annual rings of pear trees were wide after cold and rainy previous summer and after rainy previous October, while in the current year, ring width was affected by insolation in February and temperature in August (positive correlations) and precipitation in May (negative correlation). The low similarity of the ring-width pattern and effect of climate on tree-ring width between this population and a wild pear population from the Bielinek Reserve, located $200 \mathrm{~km}$ away, indicate that tree-ring width in this species is strongly dependent on habitat and there is a need to continue dendrochronological analyses.
\end{abstract}

Keywords: tree-ring width, meteorological conditions, habitat conditions, wild pear.

\section{INTRODUCTION}

Pyrus pyraster (L.) Burgsd. (= Pyrus communis ssp. pyraster $\mathrm{L}$.) is distributed in southern, central and western Europe, reaching in the east the longitude of $50^{\circ}$. It is absent from Scandinavia and north-eastern part of Russia, while infrequent in British Islands, where it reaches its northern limit near the latitude of $55^{\circ}$. In the south of Europe this species is sporadically reported from northern Spain, Sicily, Sardinia, and Corsica, but missing in Pelo-

Corresponding author: A. Cedro e-mail: anna.cedro@univ.szczecin.pl ponnese. Its isolated populations are in northernmost parts of Tunisia, Algeria, and Morocco. In Poland, $P$. pyraster has no geographic limit of distribution. It is widespread in lowlands and at lower altitudes in mountains. Some wild pear specimens are classified as $P . \times$ amphigenea Domin ex Dostálek, which are hybrids resulting from crossing of $P$. pyraster with the cultivated P. domestica Med.

Dendrochronological studies of pear trees are extremely rare. Neri et al. (2005) reported a 69-year chronology for $P$. domestica in central Italy, whereas Antkowiak et al. (2012), a 73-year chronology of $P$. pyraster from north-western Poland. 
Pear trees are light-demanding, preferring xerothermic sites, rarely forming large local populations (Hofmann, 1993; Paganová, 2003). It is no problem to find single specimens or groups of 2-3 pear trees on grassy field borders, in hedges or on roadsides, but it is difficult to find local populations composed of several dozen or more specimens. The wild pear population in the military area in Biedrusko is most probably its largest Polish population, estimated at 1000 trees.

This study was aimed to assess the age of this population, and tree growth rate, to identify major climatic factors affecting tree-ring width in this species and pointer years characteristic of this population, and to analyse their relationships with meteorological conditions.

\section{STUDY AREA}

The military training area in Biedrusko was established by Prussians in 1901. In 1940, the Nazis modernized the training grounds and expanded them to include 5 villages. After the $2^{\text {nd }}$ World War, The Polish authorities preserved the expanded military area. The villages were depopulated and most of the farm buildings were destroyed, but some components of the former rural cultural landscape in this area are still preserved after over 110 years of its use for military purposes. For example, it is easy to find remnants of the road network, planted trees (especially along roads), and some old buildings (Wilkaniec et al., 2012).

The military area covers over 7000 hectares and is bordered by the river Warta in the north and east; in the south its limits are near the villages of Radojewo and Złotniki, while in the east, near the villages of Złotkowo, Chludowo, Maniewo, Gołębowo and Gołaszyn. The headquarters are in Biedrusko $\left(52^{\circ} 32^{\prime} 34,78^{\prime \prime} \mathrm{N}\right.$ $16^{\circ} 56^{\prime} 49,34^{\prime \prime}$ ) (Fig. 1).

The area is covered to a large extent with forests, but they are generally not of high conservation value. Most of them are planted pure pine forests or poplar forests on former farmland. Oak forests are also common there, especially acidophilous oak forests Calamagrostio arundinaceae-Quercetum petraeae (Hartm. 1934) Scam. et Pass. 1959, interspaced with thermophilous oak forests (Borysiak and Brzeg, 1994).

Shrub communities are also widespread there. The largest patches, particularly in the central deforested part

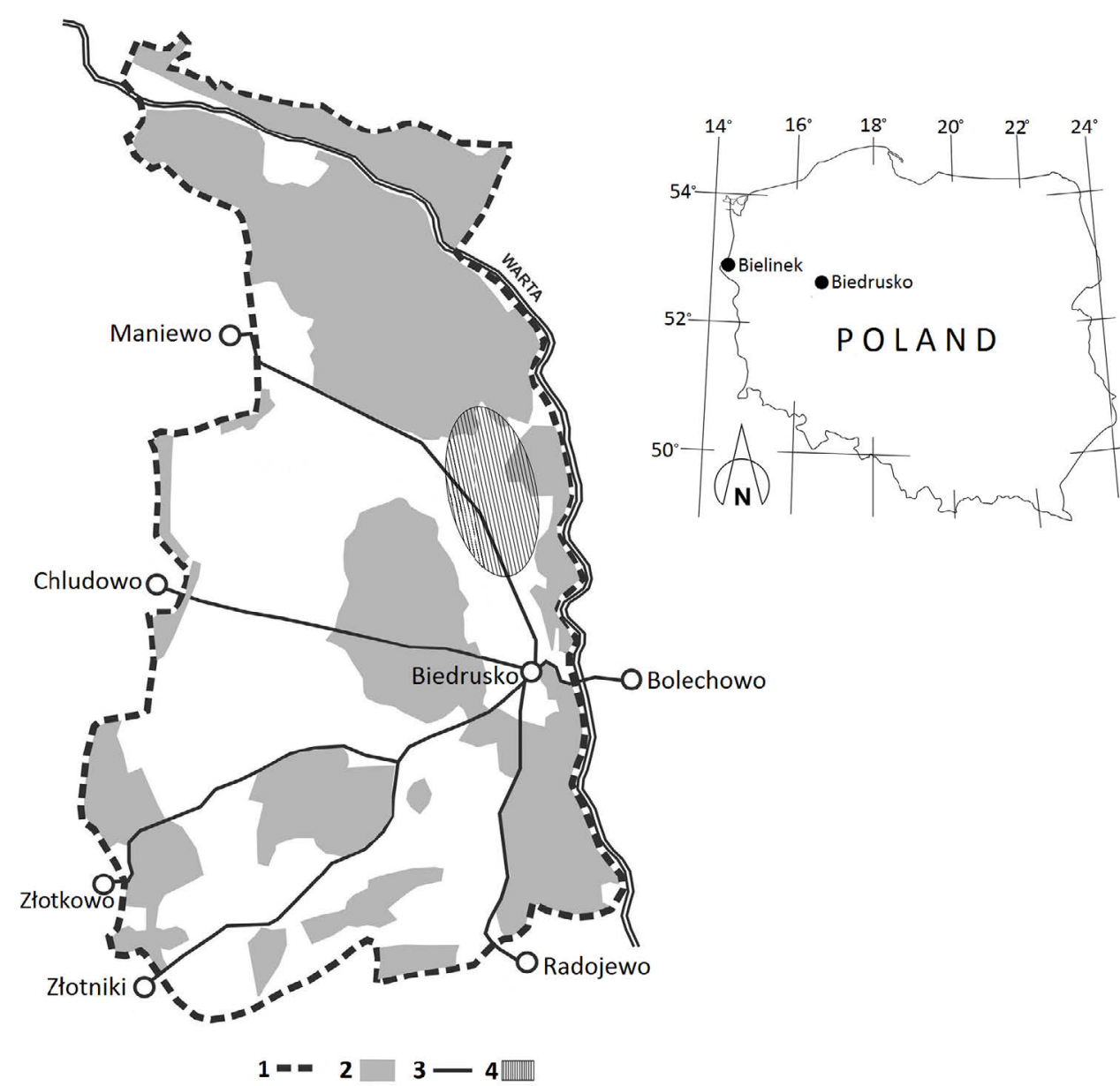

Fig. 1. Map of the investigated area: 1 - military range border, 2 - forests, 3 -roads, $4-$ local population of pear trees. 
of the military area, are thickets dominated by the common broom, Cytisus scoparius (L.) Link as well as blackthorn hedges Pruno-Crataegetum Hueck 1931 and willow thickets Salicetum pentandro-cinereae (Almq. 1929) Pass. 1961 (Borysiak and Brzeg, 1994). Well-developed thermophilous shrub communities of the class TrifolioGeranietea sanguinei Th. Müller 1962 are found along forest edges and blackthorn hedges (Walczak, 2002).

A large proportion of the area is covered by seminatural and anthropogenic meadow communities and pastures of the class Molinio-Arrhenatheretea R.Tx. 1937. Extensive elevated plains in the study area are covered by dry grassland communities, especially sandy grassland dominated by pink and thrift, DianthoArmerietum elongatae Krausch 1959. The poorest, sandy soils are covered by patches of grey hair-grass communities (Spergulo-Corynephoretum (R.Tx. 1928) Libb. 1933. Segetal and ruderal communities cover a small proportion of the study area, in comparison with those covered by the preserved natural and semi-natural vegetation (Borysiak and Brzeg, 1994).

Most soils in the study area are podzolic. In the central part of the military area they are formed from loose and weakly clayey sands, whereas in other parts, from sands on clay (Borysiak and Brzeg, 1994 after Bartkowski, 1962).

\section{MATERIAL AND METHODS}

\section{Wild pear population}

As mentioned above, the wild pear trees in the military area in Biedrusko are most probably the largest Polish population of this species, composed of about 1000 trees. Pear trees grow primarily in the northern part of the study area, on so-called "Pola Grunwaldu", north of the road from Biedrusko to Maniewo (Fig. 1). Morphological variation and genetic differentiation of $P$. pyraster from Biedrusko was earlier reported by Antkowiak (2013).

\section{Dendrochronological analyses}

In August 2007 they were conducted preliminary studies of the population, a total of 21 wild pear trees were sampled with Pressler borers. The cores were placed in special strips of wood and their surface was cut with a sharp knife to obtain a clear image of tree-rings. They were measured under a stereomicroscope, from the innermost part towards the bark, to the nearest $0.01 \mathrm{~mm}$ (Mindur, 2000). In total, 1091 tree-rings were measured. Subsequently, a chronology was assembled using the classical dendrochronological methods and tested with the COFECHA software (DPL program package, Holmes 1983, 1994).
The RES chronology (de-trended, autocorrelation removed) constructed was subjected to the indexation (using a negative exponential curve and autoregressive modelling), in order to eliminate the age trend and to emphasize the annual changeability of the annual growth ring widths, in the ARSTAN program (Cook and Holmes, 1986). The expressed population signal (EPS) analysis was used to assess the degree, to which chronologies of each plot portrayed the perfect hypothetical chronology (Wigley et al., 1984). Correlations and the response function were analysed using the RESPO program of DPL package (Holmes, 1983, 1994) for 17 months: from May of the year preceding growth to September of the year of growth. Similar analyses were performed separately for air temperature $(\mathrm{T})$ over the period of 45 years (19632007), separately for precipitation (P) over the period of 45 years (1963-2007), and separately for insolation (IN) over the period of 42 years (1966-2007). Multiple correlation coefficients $(\mathrm{R})$ and total variance explained $\left(\mathrm{r}^{2}\right)$ reflect the strength of the relationship between each analysed meteorological parameter and tree-ring width. Dendroclimatological analyses included also pointer years which is accepted method of showing annual growth reactions due to abrupt changes in environmental conditions, especially due to climatic variations. Pointer years are defined as the years when most of the sampled trees showed the same growth trend (threshold: 90\%): either decreasing (negative years) or increasing (positive years), as compared to neighbouring tree-rings. Next, the pointer year and the years preceding them were characterized in respect of thermal conditions, precipitation, and insolation. For the analyses of correlation, response function and pointer years, we used data from the nearest weather station of the Institute of Meteorology and Water Management in Poznań, located about $15 \mathrm{~km}$ south of the study area.

Mean annual temperature for this area is $8.5^{\circ} \mathrm{C}$ (in $1948-2011$ ), varying from $6.8^{\circ} \mathrm{C}$ (in 1956) to $10.2^{\circ} \mathrm{C}$ (in 2008). The warmest month is July (mean temperature $\left.18.5^{\circ} \mathrm{C}\right)$, whereas January is the coldest $\left(-1.4^{\circ} \mathrm{C}\right)$. The growing season starts in mid-March and lasts till early November (225 days of the year) (Koźmiński and Michalska, 2001). Annual precipitation is on average $528 \mathrm{~mm}$, decreasing to about $300 \mathrm{~mm}$ in the driest years (e.g. $274 \mathrm{~mm}$ in 1982 and $307 \mathrm{~mm}$ in 1984) and exceeding $700 \mathrm{~mm}$ in the wettest years $(773 \mathrm{~mm}$ in 1967). Precipitation is the highest in July $(76 \mathrm{~mm})$ and the lowest in February $(27 \mathrm{~mm})$. The number of days with precipitation is lower than 95, whereas snow cover lasts less than 40 days, reaching a maximum snow cover depth of $46 \mathrm{~cm}$ (Koźmiński and Michalska, 2001; Ustrnul and Czekierda, 2009). The mean annual sum of hours with sun for Poznań in 1966-2011 reaches 1694, varying from 1252 (in 1966) to 2031 (in 2011). Insolation is the highest in May and July (242 h/month) and the lowest in December (35 h/month). 


\section{RESULTS}

Chronology for pear trees from Biedrusko (BIE) spans 45 years (1963-2007), and is based on ring-width curves of 15 trees (Fig. 2). Mean tree-ring width is $1.92 \mathrm{~mm}$, varying from $0.60 \mathrm{~mm}$ (BIE7) to $3.46 \mathrm{~mm}$ (BIE17). Standard deviation (ST) for the chronology is 0.91 , with first-order auto-correlation (AC1) of 0.61 and mean sensitivity (MS) of 0.38 , while for the indexed chronology, the corresponding values are: STD of 0.19 , $\mathrm{AC} 1$ of 0.05 , and MS of 0.33. The Expressed Population Signal (EPS) values are above the applied threshold of 0.85: in time span 1963-2007 EPS $=0.96$ (Wigley et al. 1984). The oldest tree measured by 114 tree-rings.

For the BIE chronology, 18 pointer years were identified, including 7 positive and 11 negative ones (Fig. 2). The analysis of meteorological conditions indicates relationships between weather conditions in the year preceding formation of the tree-ring and its width. Annual rings of pear trees were wide after years with cold and rainy summer but warm, long, sunny, and dry autumn. Growth depressions were caused by dry and hot summers in the years preceding growth. The analysis of correlation and response function indicate similar relationships between tree-ring width and climate: weather conditions in the year preceding growth affect ring width in the following year (Fig. 3). For temperature (T), correlations were detected in July (negative correlation), for insolation (IN) in July, October and December (negative correlation and regression coefficients), and for precipitation (P) in July, August and October (positive values of correlation and regression). Statistically significant values for the current growing season were also recorded for temperature $(\mathrm{T})$ in August (positive values), precipitation $(\mathrm{P})$ in May (negative regression coefficient) and for insolation (IN) in February (positive relationships). Multiple correlation coefficients $(\mathrm{R})$ and total variance explained $\left(\mathrm{r}^{2}\right)$ were the highest for precipitation ( 0.72 and $52 \%)$ and insolation (0.68 and 46\%), while the lowest for temperature: 0.48 and $23 \%$. F-value for precipitation was 5.48 significant at the 0.0002 level, for insolation 4.90 significant at the 0.001 level and for temperature 2.85 significant at the 0.02 level.

\section{DISCUSSION AND CONCLUSION}

Dendrochronological studies of pear trees are very rare, probably because this species does not form dense forest stands, which are of major interest to dendrochronologists. In Poland, $P$. pyraster is most often a component of patches of thickets among fields. These shrub-dominated communities are treated as substitute communities on potential sites of oak-hornbeam forest, so they are anthropo-climax communities in the agricultural landscape. In the forest-steppe Bielinek Reserve, wild pear trees grow in xerothermic elm forests on slopes and

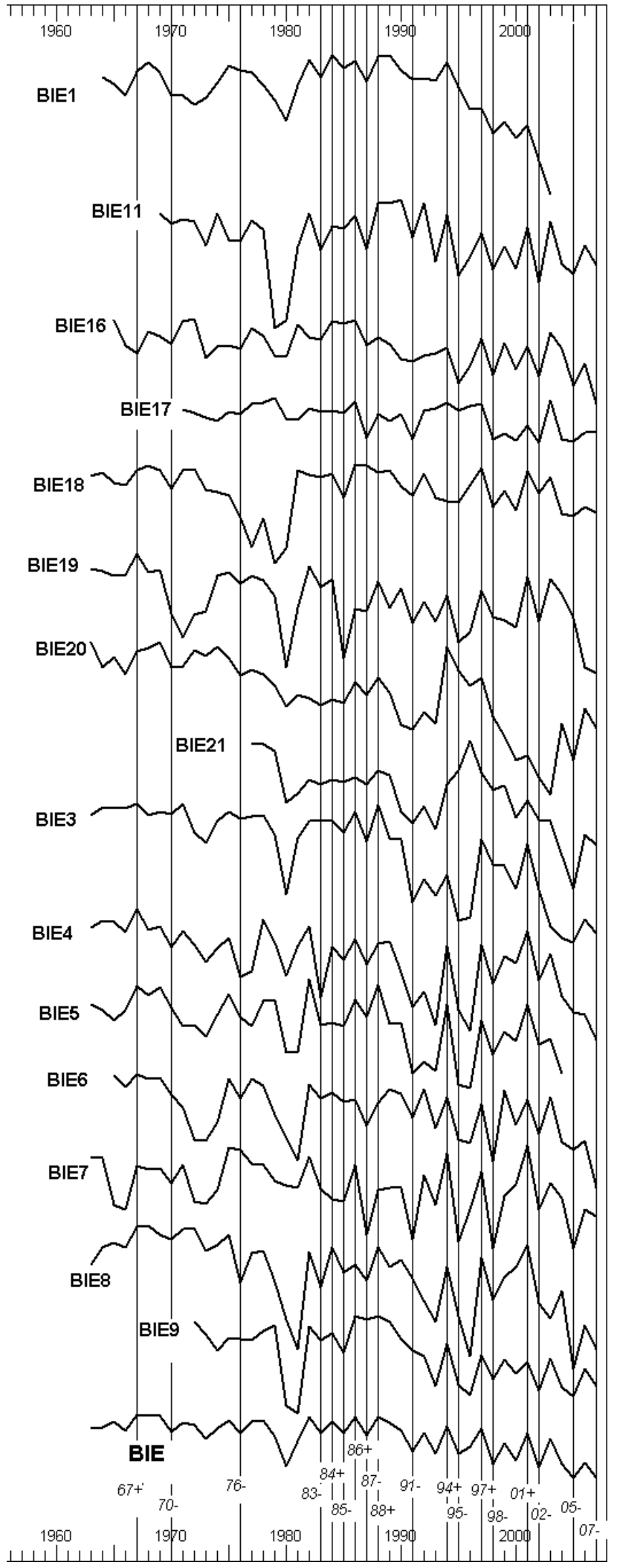

Fig. 2. Dendrochronological sequences in semi-logarithmic scale making up the wild pear chronology BIE from Biedrusko and pointer years: $(+)$ positive, $(-)$ negative pointer years. 
in thermophilous oak forest, similar in species composition and structure to sub-Mediterranean oak forests (Celiński and Filipek, 1958). Within the reserve, these specific forest communities have the only in Poland, geographically isolated locality, considered by many researchers as a relict (Milecka et al., 2004; Matuszkiewicz, 2002). For those pear-trees we previously constructed a chronology (GR) spanning 73 years (Antkowiak et al., 2012). Those trees reacted distinctly to changing weather conditions: their growth was significantly correlated with temperature in some months of the preceding year: July, August, and November (negative correlation and regression). However, tree-ring width was affected
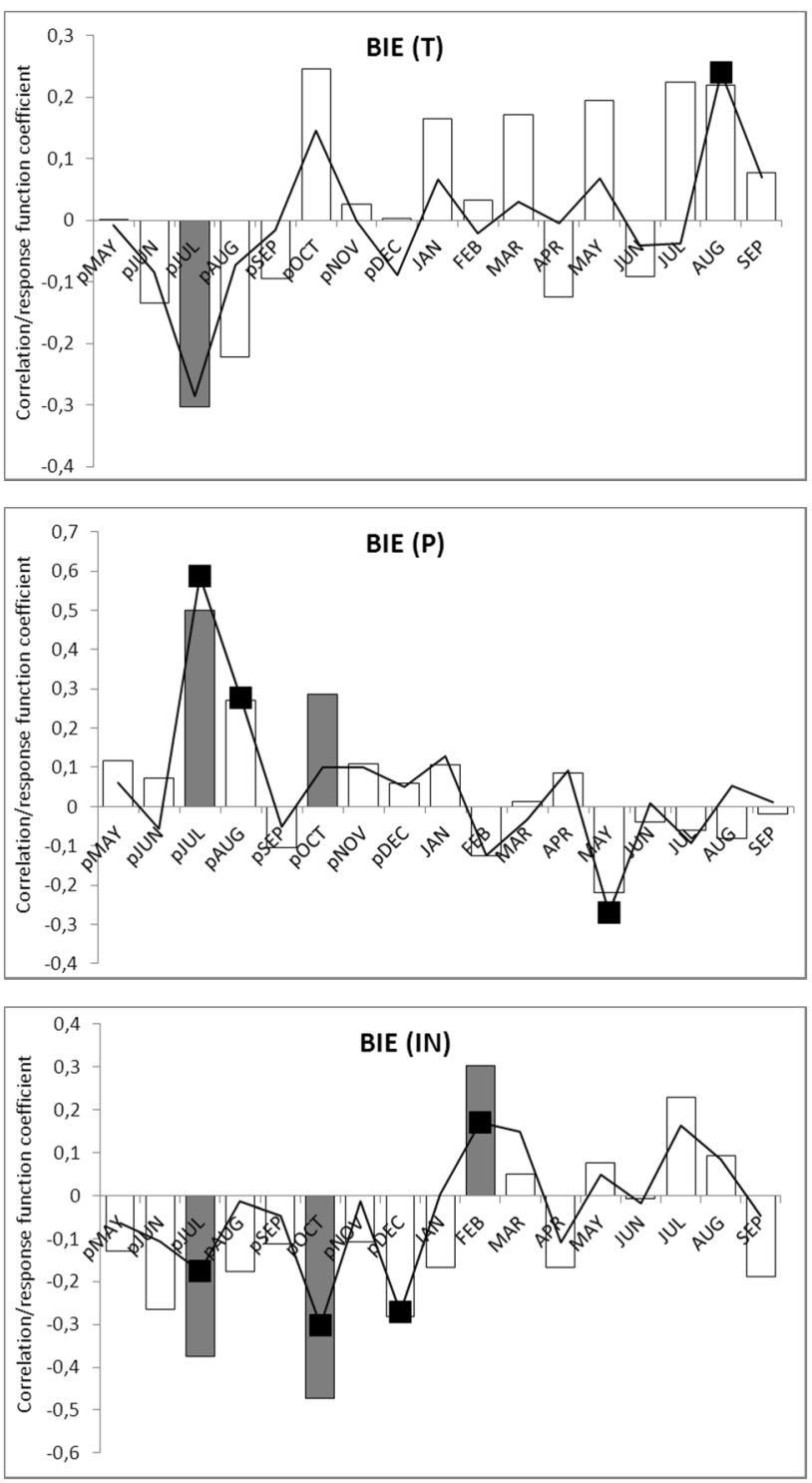

Fig. 3. Results of correlation and response function analyses for wild pear chronology (BIE) and air temperature $(T)$, precipitation $(P)$ and insolation (IN); bars denote correlation coefficients; line represents the response function; significant values $(\alpha=0.05)$ are marked as black squares and grey bars; " $p$ " before month denotes previous year. predominantly by temperature and precipitation in the current growing season (Antkowiak et al., 2012; Cedro, 2013). The analysis of pointer years as well as correlation and response function indicate that tree growth was reduced most strongly in years with droughts and high temperatures in summer, while summers with precipitation higher than average and low temperatures during the growing season were periods of high cambium activity and formation of wide tree-rings. The growth pattern and growth-climate responses of pear trees in Bielinek are very similar to the chronology for downy oak Quercus pubescens Willd. on the same site: Student's $t$ of 7.9, correlation coefficient of 0.46 , and $\mathrm{Gl}$ of $74 \%$ (Cedro, 2007, 2013). The similarity of complex chronologies for pear trees in Bielinek and Biedrusko is much lower: Student's $t$ of 4.6, correlation coefficient of 0.43 , and $G l$ of $57 \%$ (Fig. 4). This is confirmed by different growthclimate responses (analysis of pointer years, correlation, and response function). Probably the different growth responses are due to different habitats, and especially the extreme habitat conditions in Bielinek (steep, sunny slopes, lower precipitation).

Neri et al. (2005) reported a 69-year chronology (1935-2003) for $P$. domestica 'Angelica' in orchards in the Marche region (central Italy). Their mean tree-ring width was $3.41 \mathrm{~mm}$ (range: $1.93-6.07 \mathrm{~mm}$ ), i.e. about twice as high as for wild pear trees in the military area in Biedrusko (on average $1.92 \mathrm{~mm}$; range: $0.60-3.46 \mathrm{~mm}$ ), and more than thrice as high as for pear trees in Bielinek (on average $1.1 \mathrm{~mm}$ per year). However, the Italian research team studied pear trees cultivated in orchards (fertilized, pruned, protected with agrochemicals, fruiting abundantly, and, most importantly, grafted and propagated clonally). Unfortunately, for the chronology from central Italy, no dendroclimatological analyses were made.

Tree age over 114 years indicates that pear trees grew in this area when Prussians took it over for military purposes. Nevertheless, the major wave of wild pear "invasion" took place after the 2nd World War, when the Polish army took it over. Earlier the area was used for agriculture, as meadows and pastures, which did not

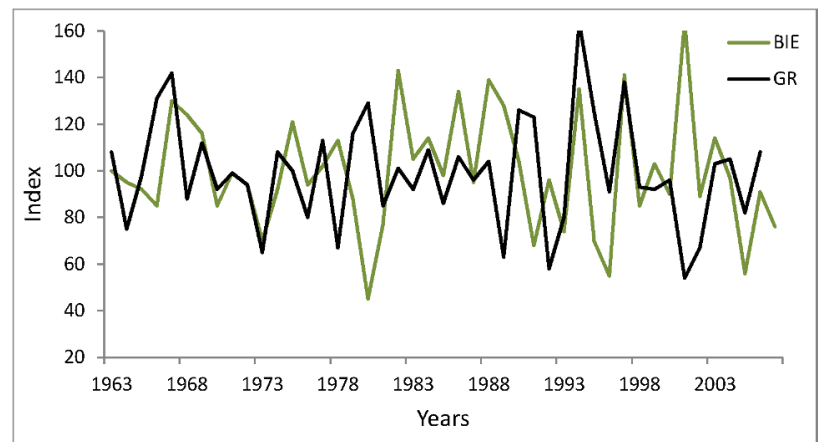

Fig. 4. Comparison of the wild pear indexes chronologies (BIE and GR) in time span 1963-2007. 
allow the development of the wild pear population. The same applies to pear trees in Bielinek: tree age clearly indicates that pear trees colonized xerothermic grasslands after creation of the reserve but before the xerothermic shrub communities developed.

The preliminary analysis of relationships between tree-ring width and weather data showed strong correlations with climatic factors in the year preceding the formation of the growth ring. Growth rings of the studied pear trees were wide after cold and rainy summer and after long, warm, sunny, and dry autumn. In the current year, tree-ring width was affected by temperature in $\mathrm{Au}-$ gust, by precipitation in May and insolation in February. Different growth patterns and growth-climate responses for wild pear populations in Biedrusko and Bielinek indicate that habitat conditions play a significant role in the process of tree-ring formation. Further dendrochronological research of pear populations is needed in all parts of their geographic range.

\section{REFERENCES}

Antkowiak W, 2013. Zmienność morfologiczna i zróżnicowanie genetyczne Pyrus pyraster (L.) Burgsd. w Polsce (Morphological variation and genetic diversity of European Wild Pear Pyrus pyraster (L.) Burgsd. in Poland). Rozprawy Naukowe 451, Wydawnictwo Uniwersytetu Przyrodniczego w Poznaniu, 127 pp. (in Polish, with English summary).

Antkowiak W, Cedro A, Prajs B, Wolko $€$ and Michalak M, 2012. Success of wild pear Pyrus pyraster (L.) Burgsd. in colonization of steep sunny slopes: an interdisciplinary study in the Bielinek Reserve (NW Poland). Polish Journal of Ecology 60(1): 57-78.

Bartkowski T, 1962. Próba kartograficznego ujęcia geomorfologii okolic Buka, Szamotuł i Skoków. Prace Komisji GeograficznoGeologicznej Poznańskiego Towarzystwa Przyjaciół Nauk 3(3): 150

Borysiak J and Brzeg A, 1994. Materiały do znajomości szaty roślinnej i propozycje ochrony cennych skupień roślinności poligonu wojskowego w Biedrusku (Plant cover of the military training camp in Biedrusko - preliminary vegetation studiem and proposals to it's protection). Badania Fizjograficzne nad Polska Zachodnia, B, XLIII, 13-170 (in Polish, with English summary).

Cedro A, 2007. Tree-ring chronologies of downy oak (Quercus pubescens), pednculate oak (Q. robur) and sessile oak (Q. petraea) in the Bielinek Nature Reserve: comparison of climatic determinants of tree ring width. Geochronometria 26: 39-45, DOI 10.2478/v10003-007-0005-2.

Cedro A, 2013. Dendrochronological analysis of Quercus pubescens and Pyrus pyraster from the Bielinek Reserve (NW Poland). Plant Diversity and Evolution 130(3-4): 195-202, DOI 10.1127/18696155/2013/0130-0065.
Celiński $\mathrm{F}$ and Filipek M, 1958. Flora i zespoły roślinne leśnostepowego rezerwatu w Bielinku nad Odrą (The flora and plant communities of the forest-steppe reserve in Bielinek on the Oder). Badania fizjograficzne nad Polska Zachodnia IV: 5-198 (in Polish, with English summary).

Cook ER and Holmes RL, 1986. Users manual for program Arstan. In: Holmes RL, Adams RK and Fritts HC, eds., Tree-ring chronologies of western North America: California, eastern Oregon and northern Great Basin. Tucson, Laboratory of Tree-Ring Research, University of Arizona. Chronology Series 6: 50-65.

Hofmann H, 1993. Zur Verbreitung und Ökologie der Wildbirne (Pyrus communis L.) in Süd- Niedersachsen und Nordhessen sowie ihrerAbgrenzung von verwilderten Kultur-birnen (Pyrus domestica Med.). Mitteilungen der Deutschen Dendrologischen Gesellschaft 81:27-69.

Holmes RJ, 1983. Computer-assisted quality control in tree-ring dating and measurement. Tree-Ring Bulletin 43: 69-78.

Holmes RJ, 1994. Dendrochronology Program Library. Users Manual. University of Arizona, Tucson.

Koźmiński C and Michalska B, 2001. Atlas of climatic risk to crop cultivation in Poland. Akademia Rolnicza w Szczecinie, Uniwersytet Szczeciński, Szczecin, $81 \mathrm{pp}$.

Matuszkiewicz JM, 2002. Zespoty leśne Polski (Forest associations in Poland). PWN Warszawa, pp. 1-358 (in Polish, with English summary).

Milecka K, Kupryanowicz M, Makohonienko I, Okuniewska-Nowaczyk I and Nalepka D, 2004. Quercus L. - Oak. In: Late Glacial and Holocene history of vegetation in Poland based on isopollen maps, Eds. Ralska-Jasiewiczowa M et al., W. Szafer Inst. of Bot., Pol. Acad. of Sc., Krakow, 444 pp.

Mindur B, 2000. Dendrometer 1,0 (Dendrometer 1.0 Software). Kraków.

Neri D, Urbinati C, Savini G and Sanchioni A, 2005. Age determination and tree-ring growth dynamic in old tree of Pyrus communis 'Angelica'. Acta Horticulturae 671, IXth Inter. Pear Symp., pp. 623629.

Paganová V, 2003. Wild pear Pyrus pyraster (L.) Burgsd. requirements on environmental conditions. Ekológia (Bratislava) 22(3): 225241

Ustrnul Z and Czekierda D, 2009. Atlas of extreme meteorological phenomena and synoptic situations in Poland. IMGW, Warszawa, $182 \mathrm{pp}$.

Walczak U, 2002. Motyle dzienne (Lepidoptera: Papilionoidea, Hesperioidea) poligonu wojskowego w Biedrusku. (Butterflies (Lepidoptera: Papilionoidea, Hesperioidea) of the Biedrusko military area). Roczniki Naukowe Polskiego Towarzystwa Ochrony Przyrody „Salamandra" 6: 103-118.

Wigley TML, Briffa KR and Jones PD, 1984. On the average value of correlated time series, with applications in dendroclimatology and hydrometeorology. Journal of Climate and Applied Meteorology 23: 201-213, DOI 10.1175/15200450(1984)023<0201:OTAVOC $>2.0 . C O ; 2$.

Wilkaniec A, Gałecka A, de Mezer E and Jeleniewska M, 2012. Relicts of agricultural and settlement landscape in the Biedrusko military training ground. Annals of Warsaw University of Life Sciences SGGW, series: Horticulture and Landscape Architecture 33: 113124. 